\title{
Trust, Race, and Welfare Reform in the American States
}

\author{
David M. Hedge, Renée J. Johnson, and Hyun Jung Yun
}

Scholars are rediscovering the social context of politics and governing, including race, trust, and, if recent elections are a guide, America's "culture wars." Social capital, that network of social relations and the accompanying norms of trust and reciprocity, is very much to the point of those dynamics. Evidence from the first round of welfare reform in the late 1990s is used to explore the relationship between elements of social capital, race and state welfare policy choices. The evidence from the welfare case suggests that one element of social capital, generalized trust, often has an independent effect on welfare policies. States with higher levels of trust are more likely to adopt welfare policies that rely on "carrots" rather than "sticks" to move individuals off welfare and into jobs. At the same time the evidence makes it clear that the influence of trust is very much conditioned by racial considerations, most notably the racial composition of welfare caseloads.

Over the last several years scholars have renewed their interest in the social context in which politics and government takes place. Hero (1998), for example, argues that social diversity - the mixture of racial/ethnic groups within a state - is the predominant influence shaping state political processes and policy outcomes. Others, most notably Fukuyama (1995) and Putnam (1995; 2000) make the case that a society's stock of social capital has a direct bearing on a community's quality of life. Social capital, the network of associations and the related attitudes of generalized trust and norms of reciprocity, is viewed by many as critical for the social, political, and economic health and well being of communities, regions, and nations. Interest in social capital has prompted a growing literature that seeks to link social capital to a range of political, economic, and social outcomes, including democratic development (Edwards and Foley 1998; Mishler and Rose 1997), the economic performance of nations and states (Helliwell and Putnam 1995; Whitely 2000; Casey and Christ 2005), collective action dilemmas (Ahn and Ostrom 2002), state and local government performance (Knack 2002; Tavits 2006), confidence in government (Brehm and Rahn 1997), the interactive effect of racial differences on political and policy outcomes (Hero 2003a; 2003b; Uslaner 2004) and support for democracy (Gibson 2001).

As promising as that research is, a number of issues need to be addressed if social capital is to have more than a heuristic value to scholars

DAVID M. HEDGE is Professor of Political Science, University of Florida, RENÉE J. JOHNSON is Assistant Professor of Political Science at Kent State University, and HYUN JUNG YUN is Assistant Professor of Political Science at Texas State University.

The American Review of Politics, Vol. 30, Winter, 2009-2010: 311-332

(C)2009 The American Review of Politics 
seeking to do empirical research. First, scholars need to be mindful that social capital is multidimensional and those dimensions are not necessarily interdependent or interchangeable either theoretically or empirically. Fischer (2001) contends, for instance, that Putnam and others are guilty of assuming that elements of social capital, including various forms of social and civic engagement and attitudes of trust and reciprocity, are intrinsically bound together, despite some evidence to the contrary. In his analysis of the American states, for instance, Knack (2002) found that while one component of social capital, generalized reciprocity, was related to state government performance, another element, social connectedness, was not. In a similar fashion, Uslaner (2004) reports that while a single index of social capital, one that combines measures of trust and social interactions, was associated with greater racial inequalities in policy outcomes at the state level (see also Hero 2003a) just the opposite held when he looked solely at the impact of one of those components - generalized trust. Outside the U.S., Gibson (2001) found that involvement in social networks fostered support among Russian citizens for democratic institutions, but attitudes of interpersonal trust did not. Taken together, those findings underscore the notion that social capital is multidimensional and its elements do not always "move" in the same direction.

Second, research on social capital needs to be careful in specifying, both theoretically and empirically, the processes by which social capital produces various political and economic outcomes within specific contexts. The available research illustrates that various elements of social capital can influence political and economic behavior in a variety of ways - reducing information and transaction costs, promoting accountability, participation and policy activism, or fostering the development of trust and duty heuristics that make cooperation easier to realize (Putnam 1993; 2000; Scholz 1998; Knack 2002; Tavits 2006). In part, scholars need to do a better job of identifying the intervening variables that link elements of social capital to social, economic or political outcomes. Putnam (2000), for example, reports a series of correlations between social capital and a number of social, economic, and political outcomes (including crime rates, economic prosperity, and indicators of child welfare), but fails to specify empirically what processes, institutions, policies, or political conditions actually channel the influence of social capital into those outcomes.

For students of the American states an additional issue arises-social capital's relationship to the larger racial context in which it operates. As Hero, Tolbert, and McNeal note $(2002,8)$ ". . . race and social capital are considerably intertwined in contemporary American society." Elsewhere Hero contends that the purported impacts of social capital are conditioned by the larger patterns of racial and social diversity. He notes (2003b, 113): 
The appropriate assessment of social capital's impact on American civil society and politics show that it depends on what dimensions of public life we consider, how we define "better off," whether one is black or white, and whether one lives in a more or less racially heterogeneous community.

The states' experiences with welfare reform provide an excellent setting within which to address those and other issues. In the pages that follow we report findings concerning the impact of social capital on welfare policy in the American states during the first round of welfare reform. That analysis is usefully reported for what it can tell us about welfare policy, social capital, and the influence of race in American politics and policy. First, our analysis can add to our understanding of the social and political forces that shape how the American states address the problems of poverty and unemployment. There is now a substantial body of evidence generated over the last several decades that attempts to account for differences in state welfare policy. For the most part, that evidence suggests that welfare policy reflects those considerations - politics, class, and race - that divide Americans and pit various groups against one another. Yet we believe a case can be made theoretically and empirically that under the right conditions welfare policy can reflect those influences that bring people together, in this instance elements of social capital.

Second, the evidence from the welfare case informs our understanding of how the influence of social capital plays out at the state level. The idea that social capital is linked with government performance is not new. There are a multitude of studies that investigate the relationship between social capital and various forms of government performance. For example, Rice and Sumberg (1997) found that social capital was most strongly associated with policy liberalism and least associated with government efficiency. Similarly, Tavits (2006) finds that among a sample of American and German cities social capital is most closely linked with policy activism rather than government efficiency. These studies do an excellent job of deconstructing the notion of social capital and investigating its relationship to different aspects of government performance. In this analysis, however, we extend this research by investigating the linkage between two aspects of social capital and government performance in a specific policy area.

Previous research (Hero 2003b; Uslaner 2004) has already investigated the relationships between various measures of social capital and policy outcomes. Rather than examining policy outcomes, such as jobs retained or number of individuals on welfare, we examine policy outputs. In particular, we examine the policy choices that state legislatures made in the aftermath of the passage of PRWORA. In this analysis, we are particularly interested in the linkages between various measures of social capital and the types of choices that state governments made about how to deliver social services. 
While there are a number of studies that examine the correlates of state policy choice (Soss et al. 2001), these studies do not include measures of social capital as potential correlates of state policy choice. In our analysis, we examine the influence of trust and social networking separately to discover which dimensions of social capital are relevant (or not) to the states' redistributive policies. As such, this study extends the research on state welfare policy by integrating the larger social capital literature with the literatures on state welfare decision making.

Third, our analysis also speaks, albeit indirectly, to the mechanisms or pathways by which social capital might influence political, economic, or social outcomes. Studies of welfare reform have found that the use of carrots (e.g., child care support) and sticks (e.g., sanctions) both work to reduce welfare caseloads and increase the rate at which welfare recipients enter the workforce (see, for example, Bell 2001; Blank 2001; or Johnson et al. 2004). While our data do not allow us to examine the direct empirical link between elements of social capital and welfare outcomes (caseloads or employment levels), our analysis can determine if social capital has an indirect role in shaping those outcomes by influencing the creation of those carrots and sticks that subsequently shape welfare outcomes.

Finally, our analysis offers additional insights into how race shapes welfare reform and whether (and how) social capital and race interact in the American states. The conventional wisdom and the research that supports it argue that welfare policies reflect racial attitudes and the racial composition of welfare caseloads including attitudes toward minorities and welfare recipients. Our findings provide additional support for that, but suggest that welfare policies also reflect at least one element of social capital, generalized trust. But even those influences are subject to larger racial considerations. As we discover, the influence of social capital exists only in those states in which the racial composition of caseloads is less than 50 percent black.

\section{Background: The States and Welfare Reform}

Analysts agree that the enactment of the Personal Responsibility and Work Opportunity Reconciliation Act of 1996 (PRWORA) was a watershed event for two reasons. First, and most obviously, the 1996 legislation ended "welfare as we know it," by eliminating the entitlement program that had been in place for over a half a century. Second, and equally important, the PRWORA shifted responsibility for what had been predominantly a federal program to the American states by replacing the entitlement program with a block grant (Temporary Assistance to Needy Families [TANF]) that allows the states to operate their own welfare programs largely as they see fit. 
Under the 1996 legislation, the states are given substantial discretion in how welfare will be implemented within their borders. As a result, there is considerable variation in state program requirements, the range of services provided welfare recipients and former recipients, and how the states organize welfare provision.

As recent studies of the content of welfare indicate, state policies in the wake of the 1996 reforms are increasingly about the various incentives the states use to motivate individuals to leave welfare and enter the world of work (Soss et al. 2001). A number of scholars (Johnson et al. 2004; Karch 2002; Gais and Weaver 2002; Riccucci et al. 2004; Zedlewski 1998) have argued, for instance, that state welfare programs are best viewed as packages of "carrots" (earning disregards, childcare support, job counseling) and "sticks" (time limits, severe sanctions, family caps) aimed at changing the behavior of recipients. In accounting for those differences scholars have discovered that many of the factors that accounted for state welfare policies in the pre-reform period also account for variations in the wake of the 1996 reforms, even though the emphasis in the post-reform era is less about benefit levels as it is about the conditions under which families would receive those benefits. There is, for example, considerable evidence that welfare policies following the passage of PRWORA continue to reflect racial and class biases. Scholars consistently find that states with a higher AfricanAmerican or Latino caseload are more likely to adopt stricter work standards and impose tougher sanctions on those recipients that fail to comply with the new work requirements (Soss et al. 2001; Gais and Weaver 2002; Fellowes and Rowe 2004; Avery and Peffley 2005). In addition, Riccucci (2005) finds that race and ethnicity may influence within-state variation in the implementation of TANF policies. There is also strong evidence to indicate that class biases are at play. Both Fellowes and Rowe and Avery and Peffley discover that an upper class bias in voter turnout produces more stringent and restrictive welfare rules. Not surprisingly, politics matter as well. States with a more liberal citizenry or legislature, more inter-party competition, and a Democratic controlled legislature adopt fewer sanctions and offer greater flexibility. We suggest that an additional state level influence, elements of social capital, is likely to shape welfare policy in the post-reform era.

\section{Social Capital and Welfare Reform}

In Bowling Alone: the Collapse and Revival of American Community (2000, 21), Robert Putnam argues that America's stock of social capital ("social networks and the associated norms of reciprocity") has declined substantially in recent decades. As Putnam $(2000,27)$ laments: 
For the first two-thirds of the twentieth century a powerful tide bore Americans into ever-deeper engagement in the life of their communities, but a few decades ago - silently, without warning - that tide reversed and we were overtaken by a treacherous rip current. Without at first noticing, we have been pulled apart from one another and from our communities over the last third of the century.

According to Putnam, a decline in civic engagement is important because of what it denies a community. As Putnam (2000) notes, the supply of social capital has a direct bearing on the quality of life within a community. Greater trust and interaction among individuals and groups provide an antidote to the problem of "free riders," lower the transaction and information costs involved in social and economic relations, and contribute to the physical and mental health and well being of individuals within the community (p. 288-289). To demonstrate his point, Putnam looks at the bivariate relationships between social capital and various measures of the quality of life among the American states. Among other things, Putnam discovers that social capital is associated with greater educational achievement, lower rates of violent crime, and healthier communities. While Putnam's analysis is by his own admission more illustrative than conclusive it does suggest the potential importance and value of social capital for understanding state level phenomenon.

Others provide more rigorous analyses and further illustrate how social capital can affect the economic, social, and political well being of the states. Knack (2002), for example, considers the effect of social capital on the quality of governing in the American states. According to Knack, social capital can potentially contribute to the quality of governing by promoting greater accountability and ultimately more efficient government. In general, social capital can promote better government by making it easier for key policy actors to reach agreement on an appropriate course of public action. In testing those assertions, Knack discovers the states' level of generalized reciprocity (including social trust and volunteerism) is associated with better governmental performance, as measured by the Government Performance Project. At the same time, he finds no evidence of any relationship between the quality of government and his measures of social connectedness and networking.

Evidence reported by Hero (2003a) and Uslaner (2004) considers the impact of the states' social capital on racial differences in policy outcomes. Hero challenges Putnam's (2000) notion that social capital promotes civic and economic equality by looking at the link between Putnam's social capital index and measures of racial differences across a number of social and educational outcomes. Hero's findings suggest that social capital is inversely related to race equality. Blacks who live in states with higher 
levels of social capital experience lower (relative to whites) high school graduation rates and higher relative rates of school suspension and incarceration. However, Uslaner's subsequent analysis suggests that at least one element of social capital, generalized trust, has a positive impact on inequality. According to his analysis, states with a high level of generalized trust have lower relative minority suspension rates and lower rates of black suspension and African-American poverty.

We suspect that those and additional dynamics operate in the case of welfare reform. In particular, we argue that elements of social capital plays an important role in the development of welfare policy. Specifically, states whose citizens report higher levels of generalized trust and more social interaction will be less likely to adopt welfare policies that rely on sanctions and more likely to adopt policies that rely on positive inducements and programs of support. Why? We believe the answer lies in the changing nature of state welfare policies and alternative views about the poor and the roots of poverty. Increasingly state welfare policies are less about benefit levels and more about finding those incentives that will move individuals off welfare and into work. Accordingly, Zedlewski (1998), Grady (1998), Karch (2002) and others have argued that various state welfare rules and requirements are usefully viewed as either "carrots" or "sticks." Carrots are those provisions in the law that offer positive incentives to work, including earning disregards, and programs that make keeping and gaining a job easier (e.g., child-support, transportation, or job counseling). Sticks, in contrast, rely on negative sanctions for failing to find and keep a job and more stringent work requirements.

The choice between carrots and sticks, in turn, relies on larger theories of poverty and attitudes toward the poor held by citizens and their representatives. Greater reliance on carrots reflects a view of poverty that lays the blame not on the poor themselves but larger social and economic forces including racism, discrimination, and a lack of training, opportunity, and support. Welfare policies in that view should aim at removing those obstacles that make finding and keeping a job difficult including childcare, job training, and transportation. A reliance on sticks (strict deadlines, work requirements, etc.) in contrast, is consistent with a view of poverty that places the blame squarely on the poor themselves and assumes that left to their own devices America's poor and unemployed would choose welfare over work. Critics of welfare have long argued that the poor are capable of working but simply lack the incentives to do so. The use of sanctions is meant to provide those incentives.

Our understanding of social capital leads us to believe that carrots and the view of poverty that support their use are consistent with the notions of trust, "connectedness," and reciprocity inherent in the concept of social 
capital, while the use of sanctions and the reasons for their use are not. The choice of carrots implies that most individuals will work given the opportunity do so. In that sense, carrots presuppose a level of trust between an individual and the community and one that is not directed at or references particular groups (i.e., minorities or welfare recipients). It is generalized trust. As Uslaner $(2004,502)$ notes "it is trust in strangers, not trust in people we already know. . . . It is trust in people who are likely to be different from ourselves." Trust in that sense is captured by the survey prompt "most people can generally be trusted to do the right thing." Moreover, those who hold these values "... are tolerant and supportive of rights for minorities that have faced discrimination ..." and "... favor programs that will make outcomes more equal, because they see American society (in particular) as marked by a common set of values and linked fate among its many groups" (Uslaner 2004, 502). A reliance on negative sanctions, in contrast, belies a more skeptical view of those on welfare and a belief that given a choice the poor will choose not to work and remain on welfare as long as they can. Such a perspective is much less likely to be grounded in the concepts of generalized trust or social engagement and more likely to be based on attitudes (typically negative) toward particular groups including minorities, the poor, or welfare recipients (see, for example, Gilens 1999).

To summarize our argument, the path between social capital and welfare policy is found in the links between theories of poverty and the use of carrots and sticks on the one hand and the fit between those theories and elements of social capital on the other. Put simply, we contend that generalized trust and social networking are consistent with a view of poverty that places the blame not on those who are poor but larger social, political, and economic forces and relies on programs of support ("carrots") to ameliorate some of those conditions. Where generalized trust is less evident citizens and lawmakers are also more likely to place the blame on the poor themselves and favor stricter work requirements and harsher sanctions ("sticks").

Our model further assumes that state lawmakers share the views of their citizens regarding trust in others and the sources of (and solutions for) poverty and act accordingly. Each of those beliefs is fairly fundamental and likely to be part of a larger political culture of ideas and beliefs in each of the states. Erickson, Wright and McIver's (1993) research on the fit between public opinion and public policy suggests one possible means by which citizen beliefs condition the policy choices of their legislatures. According to those authors' evidence, liberal publics elect liberal legislators who in turn adopt liberal policies. Although our measures of trust and citizen ideology are only moderately related $(\mathrm{R}=.15)$ we believe that similar dynamics operate in the welfare case-i.e., that citizens who are more trusting of others are more likely to vote for candidates who share and express similar views. 
Montgomery (2000) suggests an additional avenue by which elements of social capital can link citizens and their elected officials. According to that author, political leaders often make appeals to social capital when they ask their constituents to support specific public policies such as antismoking legislation, contributions to charity, recycling, etc. Montgomery also argues that social capital can become endogenous and an important part of public policy. When people cooperate with others, they sometimes do so with the expectation that that cooperation will benefit the larger group as well as themselves. Indeed, Montgomery argues that this type of cooperation may be encouraged in others who are "remote from the scene" (p. 3). When this cooperative spirit is widespread, it also can become the basis for policy initiatives. Additionally, Montgomery contends that a group's stock of social capital need not even be explicitly engaged by government to serve policy purposes. Montgomery's conceptualization, then, suggests that social capital may directly influence the policy choices that states choose. States that exhibit higher levels of generalized social trust, then, should also be states where we find such appeals more successful. As such, we would expect that legislatures can more comfortably rely on their constituents to support nurturing welfare programs in states with higher levels of generalized trust.

\section{A Model of Welfare Reform}

The model of the welfare policy estimated in this paper views the states' welfare policies as a function of the states' economies, race, the balance of political power, the ideological orientation of the states' citizenry, and, our focus here, the states' stock of social capital. Measures of each of our concepts, beginning with the elements of social capital, are described below. We agree with the political theorist James Farr (2004) when he notes that contemporary discussion of the concept of social capital "boils down to networks, norms, and trust" (p. 8). In this essay, we focus our analysis on the generalized trust and social network components of social capital.

To measure those components, we utilize two different measures drawn from data included in Putnam's (2000) analysis of the consequences of social capital across the American states. The first is a measure of generalized trust in each state that Putnam constructed from the General Social Survey and includes the mean state response to the prompt: "Most people can be trusted" vs. "Can't be too careful" over the period 1974-1996. In employing that measure, we are subscribing to the notion of generalized trust offered by Uslaner and others that view trust as "trust in strangers" (versus specific groups or individuals). Unfortunately, the trust variable has no reported values for nine states. In order to include those states in our analysis we employ 'multiple imputation using chained equations' (MICE) 
to estimate the level of trust in those states. This procedure iterates several (m) distributions for each individual variable. By imputing missing values using information drawn from the iterated distributions, this procedure does not violate the nature of variance and random sampling assumptions (King et al. 2001).

Our second measure, what we have labeled social networking, measures the social connectedness and involvement of each state's citizens. The measure is constructed as a Likert scale composed of four state level measures included in Putnam's data set - the mean number of club meetings attended in a year, the mean number of community projects individuals worked on in a year, the number of times individuals entertained in their home in a year, and the number of times individuals volunteered in a year. ${ }^{1}$

A number of indicators are used to reference the various "carrots" and "sticks" that comprise the states' welfare policies in 1997. With respect to state carrots, we begin with an ordinal score developed by Zedlewski (1998, 60 ) at the Urban Institute that reflects ". . . the amount of earnings recipients can retain and still remain eligible for a minimum TANF benefit." States are assigned to three categories. States that allow recipients to have total incomes (TANF and earned income) up to 80 percent of a full-time minimum wage receive a value of 1 ; those that allow recipients to have incomes of no more than 120 percent of a full-time minimum wage received a 2; while states that allow incomes in excess of 120 percent received a 3. Additional measures of state carrots include the number of months of transitional Medicaid funding available; whether the state provides child care for TANF families; whether the state provides transition child care for those leaving TANF; whether the state allows individual development accounts; and whether the state provides diversion assistance to enable families to avoid receiving welfare assistance (NGA 1997).

A variety of measures are used to get at state "sticks" including whether the state requires some form of drug testing of some TANF applicants; whether the state allows victims of domestic violence to waive work requirements; whether the state has a family cap policy; whether the state treats new residents differently; whether the state provides TANF for legal non-citizens; whether the state denies TANF to drug felons; whether the state has a lifetime limit on support that is less than the federal limit of 60 months; and whether the state has a work requirement shorter than 24 months. We also include an ordinal score (1-3) provided by Zedlewski's (1998) that reflects the severity of state sanctions for failing to comply with employment requirements. A higher value indicates states with the most severe sanctions.

Although more recent data are available for our measures of state welfare policy, we have chosen to concentrate our analysis on the earlier period 
for a number of reasons. First, welfare policy from the mid-nineties more closely corresponds in time to Putnam's social capital data. Second, and more importantly, the decisions the states made during what is essentially the first round of welfare reform provide an excellent vantage for observing how the states viewed the problems of and solutions for poverty and unemployment. One problem with studies that seek to explain welfare policy choices is that measures of welfare policy at any point in time may actually reflect decisions made years earlier. The problem is that scholars can find themselves explaining what are essentially old decisions with more contemporary explanations (imagine a study attempting to explain welfare decisions actually made in 1964 that use the states' 1968 presidential vote as an explanation for those earlier decisions). The states' welfare choices in the wake of PRWORA largely avoid that problem since the states were being asked to reshape their programs in a relatively short period of time. As Soss et al. (2001) note in their study of welfare during this period

Here, we have a case in which the fifty states responded virtually simultaneously to a single policy mandate. From an analytic standpoint, it is hard to imagine a stronger opportunity to pinpoint state-level policy choices.

Moreover, as Rodgers, Beamer and Payne (2008) report, the states' basic approach to welfare policy remained largely unchanged in the decade following the 1996 reforms (see also Urban Institute 2007).

Additional variables are included to tap the influence of politics, race, and class on state welfare policies in the post-reform era. First, Erickson, Wright and McIver's (1993) estimate of political ideology is used to measure the overall political philosophy of each state's citizens. We expect that more liberal publics will prefer welfare policies that are more carrot- (vs. stick) oriented. Second, over fifty years ago V.O. Key (1949) argued that governments are more likely to appeal to the disadvantaged where the two parties are more evenly matched. He argues that states with more competitive political systems are more likely to be responsive to the interests, needs, and desires of the "have nots." This occurs because parties in a competitive party system experience anxiety over election outcomes and thus, feel the need to appeal to a broader swath of the public. In contrast, states with less party competition are often dominated by fewer, wealthier, and more powerful political interests. In 1963, Dawson and Robinson engaged in one of the first fifty-state empirical tests of this theory in the specific case of welfare policy. They found that in eight of the nine categories of welfare policy they investigated, states with greater levels of party competition were more likely to adopt more generous welfare benefits. These findings have since been replicated in many studies and therefore, we use it as an important control variable in our analysis. We hypothesize that greater inter-party competition 
will be associated with state welfare policies that offer programs of support and positive inducements to move individuals off of welfare and into work. Ranney's party competition index between 1995-98 (reported in Bibby and Holbrook 1999) is used to measure that competitiveness. Third, we include the unemployment rate in 1998 to get at the influence of the states' economies. Here we are less certain as to the likely direction of the relationship. On the one hand, the labor-market thesis (see Piven and Cloward 1993; Soss et al. 2001) suggests that lower rates of unemployment produce more stringent or stick-based welfare policies as states seek to move individuals off the rolls as quickly as possible to ease tight labor markets. On the other hand, a resource model argues just the opposite - states are more inclined to adopt stringent eligibility requirements, tougher sanctions, and other relatively low cost policies (i.e., sticks) during more difficult economic times when demand for welfare services is higher and tax revenues are lower. Fourth, we include a measure of class bias in the states' electorates to get at the possibility that welfare policy reflects class differences in support for programs for the poor and minorities. A number of studies have found that an upper-class bias in turnout is associated with less generous welfare benefits (see, e.g., Hill et al. 1995; Ringquist and Hill 1997) and more restrictive welfare policies (see, e.g., Avery and Peffley 2005). The logic here is simple - individuals with higher incomes are generally less supportive of welfare and more likely to be responded to by state policy makers when they turn out at higher levels than their lower-class counterparts. We use a measure constructed by Avery and Peffley that represents the ratio of upper-class to lower-class turnout for each state in 1996 to get at that possibility. ${ }^{2}$ Our hypothesis is that higher relative levels of turnout among the states' more affluent families will be associated with welfare policies that tend toward sticks and away from carrots. Finally, we use two sets of variables to get at the influence of race. Initially, we include Hero's (1998) measure of racial diversity to control for the influence of the states' racial milieu. ${ }^{3}$ In addition, we include measures of the racial composition of each state's caseload ${ }^{4}$ to get at racial bias in the choice of welfare policies. In each case the hypothesis is clear; greater racial diversity of the states' population and/or welfare caseloads is likely to yield a more punitive approach to welfare. Race and attitudes toward welfare have been intertwined for decades in America and there is good reason to believe that negative attitudes toward welfare reflect negative perceptions and attitudes toward blacks and Hispanics (see most notably, Gilens 1999). As we note earlier, research on welfare policy in the nineties bear this out; states with larger black and Hispanic welfare populations are more likely to, among other things, impose stricter work requirements, exact harsher sanctions, and impose a family cap on recipients (Soss et al. 2001; Fellowes and Rowe 2004; Avery and Peffley 2005). 


\section{Findings}

Tables 1 and 2 report our findings concerning the impact of social capital on the character of state welfare policies. In that analysis, we created a single composite score to reflect the mix of carrots and sticks each state adopted in the mid-nineties. ${ }^{5}$ Combining carrots and sticks is consistent with the decisions the states were asked to make in the mid-nineties. Following the passage of PRWORA in 1996 the states had a relatively short time period in which to decide on the mix of carrots and sticks that would constitute their new programs of welfare. Some states like Florida, Idaho and North Carolina, for example, relied primarily on sanctions and work requirement. Others, including New York, Maine, and Illinois, concentrated on positive incentives to move individuals off of welfare including providing day care support and transitional Medicaid. Most states however, chose a mix of carrots and sticks (Johnson et al. 2004). In that sense, state welfare policies can be usefully placed on a continuum anchored on one end by positive incentives (e.g., transitional Medicaid) and on the other end by negative incentives (e.g., strict sanctions). Given the short time span in which the states would make their decisions, the overall concern with finding the right mix of incentives to move individuals off of welfare and into jobs, and the fact that an overwhelming majority of states chose to combine carrots and sticks suggest that the choices of particular program elements were not made in isolation of one another but were viewed as a larger package of incentives. In constructing our welfare policy score we first created separate carrot and stick scores ${ }^{6}$ and then subtracted the former from the latter. The resulting score ranges from -24 to +24 . A higher positive value indicates state welfare policies that rely more on carrots to induce individuals off welfare and into work.

In many ways the evidence in Tables 1 and 2 mirrors that from studies of welfare policy conducted both prior to and following the latest round of reform. Although the key policy issues have shifted from who should receive aid (and how much) to the question of what governments should do to move individuals off welfare and into jobs, the data suggest that welfare policy remains very much a political choice. States with greater inter-party competition and, less frequently, more liberal publics are more likely to rely on carrots and programs of support than sanctions or sticks. In addition, states in which lower-class turnout is low relative to upper-class voters proved more likely to adopt welfare policies that are more heavily skewed to sticks and sanctions.

For our purposes, the more important findings in Tables 1 and 2 concern the influence of generalized trust and race on welfare policy choices. As the data make clear, that influence depends on which aspect of race is con- 
sidered and, for that matter, how much race is involved. The evidence from the first round of welfare reform indicates that while the larger pattern of racial diversity has little impact on the welfare policy process, the racial composition of the states' caseloads does, conditioning not only the influence of trust on welfare policies and outcomes, but other explanations as well. These points are elaborated below.

The analyses reported in the first two columns of Table 1 include Hero's diversity measure as our indicator of race. As we note above, Hero has argued that social capital and race are intrinsically bound together in America. Noting the strong inverse relation between diversity and social capital, Hero (2003a; 2003b) posits that the impact of social capital is likely to be conditioned by the level of racial diversity. Elsewhere, Hero and his colleagues (Hero et al. 2002) suggest that the observed relationship between social capital and political outcomes is largely spurious. The data reported in the first two columns of Table 1 provide little evidence in support of either assertion. As the data indicate, generalized trust has a significant and independent effect even after controlling for racial diversity and various political influences. States whose citizens exhibit a higher level of trust are more likely to rely on carrots in fashioning welfare policy. At the same time, social networking levels are not related to welfare policy choices, a finding that underscores the need to consider the elements of social capital separately. There is also no evidence that racial diversity has a direct or indirect effect on welfare policy. Racially diverse states are neither more nor less likely to adopt more punitive welfare policies than their less diverse neighbors. Nor is there any evidence that diversity conditions the impact of trust. To test that possibility we re-estimated the model reported in the first column of Table 1 by adding an interaction term between trust and racial diversity. According to the coefficients in the second column of Table 1, the interactive term is unrelated to the policy variable and trust continues to exert an independent effect on the states' welfare decisions. In short, racial diversity seems to have little immediate influence on state welfare policy.

None of that is meant to suggest that race has no bearing on trust or welfare policy, however. As the data in column 3 in Table 1 indicate, when we include measures of the racial composition of the states' welfare caseloads, race has a direct influence on state policy choices and, equally important, the relationship between trust and state welfare policy disappears. Although Hispanic caseloads are not related to welfare choices, ${ }^{7}$ states with a greater proportion of black recipients are more likely to adopt programs that rely more on sticks than carrots. The final column of coefficients in Table 1 provides additional information on how the racial composition of the states' caseloads influences welfare dynamics and suggests that racial composition's most important role is to condition the effects of trust. Once we 


\section{Table 1. Accounting for the Content of State Welfare Policies (standard errors in parentheses)}

\begin{tabular}{|c|c|c|c|c|}
\hline & Model 1 & Model 2 & Model 3 & Model 4 \\
\hline Constant & $\begin{array}{l}-21.119 \\
(20.354)\end{array}$ & $\begin{array}{l}-26.789 \\
(21.559)\end{array}$ & $\begin{array}{c}-1.433 \\
(20.821)\end{array}$ & $\begin{array}{c}-9.057 \\
(20.818)\end{array}$ \\
\hline Trust & $\begin{array}{l}0.241^{* *} \\
(0.108)\end{array}$ & $\begin{array}{l}0.380^{* *} \\
(0.200)\end{array}$ & $\begin{array}{c}0.029 \\
(0.135)\end{array}$ & $\begin{array}{r}0.225^{*} \\
(0.161)\end{array}$ \\
\hline Social Network Levels & $\begin{array}{c}0.001 \\
(0.001)\end{array}$ & $\begin{array}{c}0.001 \\
(0.001)\end{array}$ & $\begin{array}{c}0.001 \\
(0.001)\end{array}$ & $\begin{array}{c}0.001 \\
(0.001)\end{array}$ \\
\hline Citizen Ideology & $\begin{array}{c}0.146 \\
(0.168)\end{array}$ & $\begin{array}{c}0.243 \\
(0.206)\end{array}$ & $\begin{array}{c}0.213 \\
(0.166)\end{array}$ & $\begin{array}{l}0.331^{* *} \\
(0.179)\end{array}$ \\
\hline Inter-party Competition 95-98 & $\begin{array}{c}31.115^{* *} \\
(13.840)\end{array}$ & $\begin{array}{l}29.570 * * \\
(14.023)\end{array}$ & $\begin{array}{l}29.322 * * \\
(13.000)\end{array}$ & $\begin{array}{c}28.769 * * \\
(12.014)\end{array}$ \\
\hline Class Bias in Turnout & $\begin{array}{l}-0.095 * * \\
(0.051)\end{array}$ & $\begin{array}{l}-0.080^{*} \\
(0.054)\end{array}$ & $\begin{array}{l}-0.088 * * \\
(0.047)\end{array}$ & $\begin{array}{l}-0.090 * * \\
(0.046)\end{array}$ \\
\hline Unemployment Rate 1998 & $\begin{array}{c}1.540 \\
(1.203)\end{array}$ & $\begin{array}{c}1.477 \\
(1.210)\end{array}$ & $\begin{array}{c}0.389 \\
(1.202)\end{array}$ & $\begin{array}{c}0.243 \\
(1.159)\end{array}$ \\
\hline $\begin{array}{l}\text { Hero's (1998) } \\
\text { Minority Diversity Measure }\end{array}$ & $\begin{array}{l}-3.846 \\
(7.523)\end{array}$ & $\begin{array}{c}20.152 \\
(29.985)\end{array}$ & & \\
\hline$\%$ of Case Load Black & & & $\begin{array}{l}-0.121 * * * \\
(0.049)\end{array}$ & $\begin{array}{c}0.128 \\
(0.138)\end{array}$ \\
\hline$\%$ of Case Load Hispanic & & & $\begin{array}{l}-0.069 \\
(0.075)\end{array}$ & \\
\hline Interaction Trust $\mathrm{x}$ Diversity & & $\begin{array}{l}-0.585 \\
(0.708)\end{array}$ & & \\
\hline Interaction Trust $\mathrm{x}$ Percent of $\mathrm{E}$ & lack & & & $\begin{array}{l}-0.005^{* *} \\
(0.003)\end{array}$ \\
\hline $\begin{array}{l}\text { Number of Observations } \\
\text { Adjusted } \mathrm{R}^{2} \\
\text { F-value }\end{array}$ & $\begin{array}{l}46 \\
0.272 \\
3.403 * * *\end{array}$ & $\begin{array}{l}46 \\
0.266 \\
3.038^{* * *}\end{array}$ & $\begin{array}{l}46 \\
0.353 \\
4.064 * * *\end{array}$ & $\begin{array}{l}46 \\
0.389 \\
4.582 * * *\end{array}$ \\
\hline \multicolumn{5}{|c|}{$\begin{array}{l}{ }^{*} \mathrm{p}<.10,{ }^{*} \mathrm{p}<.05, * * * \mathrm{p}<.01 \\
\text { Notes: The significance test for the employment measure is two-tailed; significance tests for all other } \\
\text { coefficients are one-tailed. The dependent variable measures the nature of a state's welfare program. } \\
\text { The possible values for the variable range between }-24 \text { and }+24 \text {. A negative score indicates a state } \\
\text { that emphasizes stick-style welfare policy while a positive score indicates a state that emphasizes } \\
\text { carrot-style welfare policy. Alaska, Hawaii, and Nevada have missing data on the ideology variable. } \\
\text { Nebraska is excluded because of no observation on the inter-party competition variable. }\end{array}$} \\
\hline
\end{tabular}


introduce an interaction term between black caseload composition and trust three things happen - the main effects of racial composition largely vanish, the effects of trust begin to reappear, while the interaction term has a negative relationship with the welfare policy measure. In substantive terms that latter finding indicates that the influence of trust on welfare diminishes as blacks make up a larger share of their states' caseloads.

Although the small number of cases makes the analysis somewhat problematic, ${ }^{8}$ Table 2 provides additional information on how race and trust interact in the welfare context by re-estimating the model in Table 1 once the states have been divided into two groups - those states in which a majority of recipients are black $(\mathrm{n}=17)$ and those states where blacks make up less than a majority of the welfare caseload $(n=29)$. The findings are striking. ${ }^{9}$ Among the 17 states in which blacks make up a majority of recipients, state policy choices prove unrelated to all but class turnout bias. Although the relationship is relatively weak, states where turnout rates are biased toward the upper class are also those states that rely more heavily on sticks to move individuals off welfare. In contrast, where blacks make up less than fifty percent of a state's caseload, state choices respond to a number of political influences and, most importantly, to generalized trust. States with more liberal and trusting publics as well as those states with a closer balance between the two parties choose welfare programs that are relatively reliant on positive incentives and programs of support.

\section{Discussion}

Welfare policy in the American states is more complex than previously imagined. No less than four forces operate to shape welfare policies. Three of those-race, class, and politics - are well known and acknowledged throughout the literature on welfare policy. The fourth, patterns of generalized trust, is not. Yet as the evidence indicates trust matters. As we have seen, in a majority of the American states greater levels of generalized trust produce welfare policies that are more likely to rely on carrots and programs of support than they are sticks and sanctions.

In addition to what those findings can tell us about welfare policy, the data have implications for our understanding of social capital and an appreciation of the social context within which governing takes place. First, evidence of a link between trust and welfare policy is consistent with those who have argued in recent years the centrality of trust in society (see, most notably, Fukuyama 1995; Braithwaite and Levi 1998; Cook 2001). At the same time, our findings challenge the notion that feelings of trust must be specific to an individual actor(s) and individual act(s) as Hardin $(2002,9)$ and others suggest when they define trust as "A trusts B to do X." 


\section{Table 2. Race and the Content of State Welfare Policies (standard errors in parentheses)}

\begin{tabular}{|c|c|c|}
\hline & $\begin{array}{l}\text { States with }>50 \% \\
\text { of Case Load Black }\end{array}$ & $\begin{array}{l}\text { States with }<50 \% \\
\text { of Case Load Black }\end{array}$ \\
\hline Constant & $\begin{array}{l}26.075 \\
(42.897)\end{array}$ & $\begin{array}{l}-26.991 \\
(23.365)\end{array}$ \\
\hline Trust & $\begin{array}{l}-0.114 \\
(0.283)\end{array}$ & $\begin{array}{l}0.262^{* *} \\
(0.134)\end{array}$ \\
\hline Citizen Ideology & $\begin{array}{c}0.217 \\
(0.441)\end{array}$ & $\begin{array}{l}0.245^{*} \\
(0.153)\end{array}$ \\
\hline Inter-party Competition 95-98 & $\begin{array}{c}5.736 \\
(33.786)\end{array}$ & $\begin{array}{l}34.790^{* *} \\
(14.551)\end{array}$ \\
\hline Class Bias in Turnout & $\begin{array}{l}-0.116^{*} \\
(0.085)\end{array}$ & $\begin{array}{l}-0.056 \\
(0.058)\end{array}$ \\
\hline Unemployment Rate 1998 & $\begin{array}{l}-0.906 \\
(3.301)\end{array}$ & $\begin{array}{c}0.755 \\
(1.236)\end{array}$ \\
\hline $\begin{array}{l}\text { Number of Observations } \\
\text { Adjusted } \mathrm{R}^{2} \\
\text { F-value }\end{array}$ & $\begin{array}{l}17 \\
-0.193 \\
0.482\end{array}$ & $\begin{array}{l}29 \\
0.302 \\
3.421 * *\end{array}$ \\
\hline \multicolumn{3}{|c|}{$\begin{array}{l}{ }^{*} \mathrm{p}<.10,{ }^{* *} \mathrm{p}<.05, * * * \mathrm{p}<.01 \\
\text { Note: The significance test for the employment measure is two-tailed; significance tests for all other } \\
\text { coefficients are one-tailed. The dependent variable measures the nature of a state's welfare program. } \\
\text { The possible values for the variable range between }-24 \text { and }+24 \text {. A negative score indicates a state } \\
\text { that emphasizes stick-style welfare policy while a positive score indicates a state that emphasizes } \\
\text { carrot-style welfare policy. Alaska, Hawaii, and Nevada have missing data on the ideology variable. } \\
\text { Nebraska is excluded because of no observation on the inter-party competition variable. }\end{array}$} \\
\hline
\end{tabular}

As Putnam (2000), Uslaner (2004) and others demonstrate, one form of trust, generalized trust, is not specific to particular groups or actions. It is as Uslaner notes trust in "strangers" including individuals and groups that fall outside the mainstream of society.

Second, our findings underscore the need to differentiate between the elements of social capital. While generalized trust and social networks are related, the evidence suggests that they differ in terms of their relevance to and influence on state policy-making. Moreover, our findings provide some support for Uslaner's $(2004,502)$ assertion that general trust is not the result of our experiences as adults (including membership in social groups) but something that "... we learn early in life." Apparently what matters is not whether citizens "bowl alone" but that they intrinsically trust one another. 
Third, the welfare case offers some insight into the mechanisms and processes by which social capital, particularly generalized trust, influences larger social, economic, and political outcomes. As we note earlier, there is no shortage of evidence to suggest that various carrots (e.g., child care and transitional Medicaid) and sticks (e.g., work requirements and sanctions) shape welfare outcomes including caseload levels and workforce participation (see, most notably Bell 2001; Blank 2001; Johnson et al. 2004). Our findings suggest that social capital plays an indirect role in shaping those outcomes by influencing the creation of public policies that subsequently shape welfare outcomes. Ironically, if we are correct, and assuming that the states' carrots and sticks have their intended impacts on welfare outcomes, then it is likely that social capital will both contribute to (by promoting the use of carrots) and detract from (by reducing the likelihood of sticks) successful welfare reform.

Fourth, the evidence provides considerable insight into how race and trust interact in the American states and, for that matter, the role race plays in the welfare context. The impact of trust is clearly contingent upon race. But not the states' overall level of diversity as Hero and others suggest. Instead the conditioning influence of race is found in the extent to which welfare in a state is a "black" phenomenon. In those states where a majority of the state's caseload is African-American feelings of trust have little effect on the choice of welfare policy, as race seems to crowd out the influence of trust and the other variables that typically account for differences in state welfare policy. In those instances, Schram $(2005,254)$ would suggest “. . . that welfare reform is a particular type of racial regime." But in a majority of states, those with (ironically) a more diverse caseload (i.e., not majority black), general attitudes of trust produce a distinct mix of welfare policies that rely more on support than sanctions. That finding is important because it suggests that welfare choices can and do reflect larger social attitudes that are not based solely on class and race.

Fifth, evidence from the welfare case is consistent with Mead (2004) and others who argue that the character and quality of state welfare reflects the states' larger political culture. Our sense is that while generalized trust is distinct from the elements that define political culture (e.g., attitudes toward the proper role of government or the level of professionalism within government), attitudes of trust and reciprocity are probably a necessary condition for those moralistic states that appeal to a "public interest." After all, where citizens trust one another it is obviously much easier to formulate and work toward common interests. In contrast, where citizens lack that trust then the kinds of politics and government seen in those states with an individualist or traditionalistic culture are more likely to prevail. 
Finally, the analysis from the first round of welfare reform is suggestive of how subsequent research on welfare might proceed. Clearly our findings underscore the notion the race continues to be a powerful force in making and implementing welfare policies. We agree with Schram that in many instances welfare policy constitutes a racial regime. But our findings also suggest the possibility that more "communal" impulses (general trust, e.g.) can guide welfare decisions. One fruitful avenue for research would be to look at how those and other political, social, and political forces interact as welfare policy plays out in the new century. In a related fashion, analysis that pools data across several time periods can overcome some of the small $\mathrm{N}$ problems that our and other cross-sectional analyses encounter and provide insight into how the sources of welfare policy interact over time and space.

\section{NOTES}

${ }^{1}$ Factor analysis was performed to determine the extent to which the four measures load on a single dimension. The resulting factor scores and matrix indicate that the four variables have high factor loading scores $(\geq .57)$ on the new factor.

${ }^{2}$ We thank those authors for sharing their data with us.

${ }^{3}$ Hero's index uses 1996 census data and is calculated using the following formula: minority diversity $=1-\left[(\text { proportion Latino })^{2}+(\text { proportion black })^{2}+(\text { proportion white })^{2}\right.$

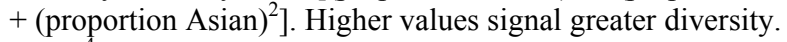

${ }^{4}$ Using data from ACF, two measures were created-\% of TANF families black and \% of TANF families Hispanic in 1998.

${ }^{5}$ We re-estimated the models reported in Table 1 and 2 using separate summary scores for state carrots and sticks. That analysis produced few differences in our overall findings concerning trust, race, and welfare reform.

${ }^{6}$ In each case we simply counted the number of carrot (stick) policies each state adopted and multiplied the result by Zedlewski's ordinal carrot or stick score. Because we include fewer carrots than stick policies in our analysis we rescaled the carrot score so that it also ranged from 0 to 24 .

${ }^{7}$ As it turns out the Hispanic measure was unrelated to trust, welfare policy, and the black caseload variable. We subsequently dropped it from our analysis.

${ }^{8}$ The advantage of physical controls as a means of controlling the influence of a conditional variable (in this case whether the states' welfare caseload is majority black) is that it allows the analyst to see not only how the influence of individual variables vary by level of the control variable, but how the overall model responds to those differing levels. The disadvantages of that approach in this case is 1) the small $n$ that results and 2) that analysis only considers two levels of the racial composition of the states' welfare caseloads.

${ }^{9}$ As was the case in Table 1, the level of social networking is unrelated to welfare policy in each set of states and was subsequently dropped from the analyses reported in Table 2. 


\section{REFERENCES}

Ahn, T.K., and Elinor Ostrom. 2002. Social Capital and the Second-Generation Theories of Collective Action: An Analytical Approach to the Forms of Social Capital. Paper prepared for delivery at the 2002 Annual Meeting of the American Political Science Association, Boston, August 29-September 1, 2002.

Avery, James M., and Mark Peffley. 2005. Voter Registration Requirements, Voter Turnout, and Welfare Eligibility Policy: Class Bias Matters. State Politics and Policy Quarterly 5(1):47-67.

Barrilleaux, Charles, Thomas Holbrook, and Laura Langer. 2002. Electoral Competition, Legislative Balance, and American State Welfare Policy. American Journal of Political Science 46:415-427.

Bartik, Timothy J., and Randall W. Eberts. 1999. Examining the Effect of Industry Trends and Structure on Welfare Caseloads. Pp. 119-158 in Economic Conditions and Welfare Reform, ed. Sheldon H. Danziger. Kalamazoo, MI: W.E. Upjohn Institute for Employment Research.

Bell, Stephen. 2001. Why are Welfare Caseloads Falling? Washington, DC: Urban Institute.

Bibby, John, and Thomas Holbrook. 1999. Parties and Elections. In Politics in the American States: A Comparative Analysis, eds. Virginia Gray, Russell L. Hansen, and Herbert Jacob. Washington, DC: Congressional Quarterly Press.

Blank, Rebecca. 2001. What Causes Public Assistance Caseloads to Grow? Journal of Human Resources 36 (1):85-119.

Braithwaite, Valerie, and Margaret Levi, eds. 1998. Trust and Governance. New York: Russell Sage.

Brehm, John, and Wendy Rahn. 1997. Individual-Level Explanations for the Causes and Consequences of Social Capital. American Journal of Political Science 41(3):9991023.

Casey, Terrence, and Kevin Christ. 2005. Social Capital and Economic Performance in the American States. Social Science Quarterly 86(4):826-845.

Cook, Karen S., ed. 2001. Trust in Society. Nework: Russell Sage.

Dawson, Richard, and James A. Robinson. 1963. Inter-Party Competition, Economic Variables, and Welfare Policies in the American States. The Journal of Politics 25(2):265-289.

Edwards, Bob, and Michael Foley. 1998. Civil Society and Social Capital Beyond Putnam. American Behavioral Scientist 42(1):124-139.

Erikson, Robert S., Gerald C. Wright, and John P. McIver. 1993. Statehouse Democracy: Public Policy and Opinion in the American States. New York: Cambridge University Press.

Farr, James. 2004. Social Capital: A Conceptual History. Political Theory 32(1):6-33.

Fellowes, Matthew C., and Gretchen Rowe. 2004. Politics and the New American Welfare States. American Journal of Political Science 48:362-373.

Fischer, Claude S. 2001. Bowling Along: What's the Score. Presented at the annual meeting of the American Sociological Association, Anaheim, California.

Fukuyama, Francis. 1995. Trust. New York: Basic Books.

Gais, Tom, and Kent Weaver. 2002. State Policy Choices. Brookings Welfare Reform and Beyond Policy Brief No. 21, April 2002.

Gibson, James L. 2001. Social Networks, Civil Society, and the Prospects for Consolidating Russia's Democratic Transition. American Journal of Political Science 45:51-69. 
Gilens, Martin. 1999. Why Americans Hate Welfare. Chicago: University of Chicago Press.

Grady, Dennis. 1998. State Government Administrative Capacity and Welfare Reform Implementation. Presented at the Annual Meeting of the American Political Science Association, Boston.

Hardin, Russell. 2002. Trust and Trustworthiness. New York: Russell Sage.

Helliwell, John F., and Robert D. Putnam. 1995. Economic Growth and Social Capital in Italy. Eastern Economic Journal 21(3):295-307.

Hero, Rodney E. 1998. Faces of Inequality: Social Diversity in American Politics. New York: Oxford University Press.

Hero, Rodney E. 2003a. Multiple Traditions in American Politics and Racial Policy Inequality. Political Research Quarterly 56(4):401-408.

Hero, Rodney E. 2003b. Social Capital and Racial Inequality in America. Perspectives on Politics 1(1):113-122.

Hero, Rodney E., and Caroline J. Tolbert. 1996. A Racial/Ethnic Diversity Interpretation of Politics and Policy in the State of the U.S. American Journal of Political Science 40(3):851-871.

Hero, Rodney E., Caroline J. Tolbert, and Ramona McNeal. 2002. Race and Community as Influences on Political Participation: Social Diversity and Social Capital Considered. Presented at the annual meeting of the American Political Science Association, August 29-September 1, Boston.

Hill, Kim Quaile, Jan E. Leighley, and Angela Hinton-Andersson. 1995. Lower-Class Mobilization and Policy Linkage in the U.S. States. American Journal of Political Science 39(1):75-86.

Johnson, Renée J., David Hedge, and Marian Currinder. 2004. Bootstraps and Benevolence: A Comparative Test of the States' Capacity to Effect Change in Welfare Outcomes. State and Local Government Review 36(1):118-129.

Karch, Andrew. 2002. Carrots, Sticks, and Welfare Reform: Are the States Racing to the Bottom? Presented at the annual meeting of the American Political Science Association, August 29-September 1, Boston.

Key, Jr., V.O. 1949. Southern Politics in State and Nation. New York, NY: Alfred A. Knopf.

Knack, Stephen. 2002. Social Capital and the Quality of Government: Evidence from the States. American Journal of Political Science 46(4):772-785.

King, Gary, James Honaker, Anne Joseph and Kenneth Scheve. 2001. Analyzing Incomplete Political Science Data. American Political Science Review 95(1):49-69.

Levine, Phillip B., and Diane M. Whitmore. 1998. The Impact of Welfare Reform on the AFDC Caseload. Pp. 24-33 in Proceeding of the National Tax Association's Ninetieth (1997) Annual Conference. Washington, DC: National Tax Association.

Mead, Lawrence M. 2004. State Political Culture and Welfare Reform. Policy Studies Journal 32(2):271-296.

Mishler, William, and Richard Rose. 1997. Trust, Distrust and Skepticism: Popular Evaluations of Civil and Political Institutions in Post-Communist Societies. Journal of Politics 59:418-451.

Montgomery, John D. 2000. Social Capital as a Policy Resource. Policy Sciences 33(3/4): 227-243.

National Governors Association. 1997. Current Trends and Emerging Issues in Welfareto-Work.

Piven, Frances Fox, and Richard A. Cloward. 1993. Regulating the Poor: the Functions of Public Welfare. New York: Vintage Books. 
Portes, Alejandro. 1998. Social Capital: Its Origins and Applications in Modern Sociology. Annual Review of Sociology 24:1-24.

Putnam, Robert D. 1993. Making Democracy Work: Civic Traditions in Modern Italy. Princeton, NJ: Princeton University Press.

Putnam, Robert D. 1995. Tuning In, Tuning Out: The Strange Disappearance of Social Capital in America. P.S. Political Science and Politics 28(4):664-683.

Putnam, Robert D. 2000. Bowling Alone: The Collapse and Revival of American Community. New York: Simon and Schuster.

Riccucci, Norma M. 2005. Street-Level Bureaucrats and Intrastate Variation in the Implementation of Temporary Assistance for Needy Families Policies. Journal of Public Administration Research and Theory 15(1):89-111.

Riccucci, Norma M., Marcia K. Meyers, Irene Lurie, and Jun Seop Han. 2004. The Implementation of Welfare Reform Policy: The Role of Public Managers in FrontLine Practices, Public Administration Review 64(4):438-448.

Rice, Tom W., and Alexander F. Sumberg. 1997. Civic Culture and Government Performance in the American States. Publius: The Journal of Federalism 27:99-114.

Ringquist, Evan J., and Kim Quaile Hill. 1997. Lower-class Mobilization and Policy Linkage in the U.S. States: A Correction. American Journal of Political Science 41(1):339-344.

Rodgers, Harrell R., Glean Beamer, and Lee Payne. 2008. No Race in Any Direction: State Welfare and Income Regimes. Policy Studies Journal 36(4):525-543.

Scholz, John T. 1998. Trust, Taxes, and Compliance. In Trust and Governance, eds. Virginia Braithwaite and Margaret Levi. New York: Russell Sage Foundation.

Schram, Sanford F. 2005. Contextualizing Racial Disparities in American Welfare Reform: Toward a New Poverty Research. Perspectives on Politics 3:253-268.

Soss, Joe, Sanford F. Schram, Thomas P. Vartanian, and Erin O’Brien. 2001. Setting the Terms of Relief: Explaining State Policy Choices in the Devolution Revolution. American Journal of Political Science 45:378-395.

Tavits, Margit. 2006. Making Democracy Work More? Exploring the Linkage between Social Capital and Government Performance. Political Research Quarterly 59:211225.

Urban Institute. 2007. Welfare Rules Database [Online]. http://www.urban.org/ uploadPDF/ 411183 wrd 2003.PDF.

Uslaner, Eric M. 2004. Trust and Social Bonds: Faith in Others and Policy Outcomes Reconsidered. Political Research Quarterly 57:501-507.

Whitely, Paul F. 2000. Economic Growth and Social Capital. Political Studies 48:443466.

Woolcock, Michael. 1998. Social Capital and Economic Development: Toward a Theoretical Synthesis and Policy Framework. Theory and Society 27(2):151-208.

Zedlewski, Sheila R. 1998. States' New TANF Policies: Is the Emphasis on Carrots or Sticks. Policy \& Practice of Public Human Services 56:57-64. 